\title{
STUDENTS PERCEPTION ON INTERNAL ASSESSMENT IN ANATOMY
}

\section{Swapnali Shamkuwar *1, Varsha Mokhasi ${ }^{2}$.}

${ }^{{ }_{1}}$ Assistant Professor, Department of Anatomy, Vydehi Institute of Medical Sciences \& Research Centre, Bangalore, Karnataka, India.

${ }^{2}$ Professor \& HOD, Vydehi Institute of Medical Sciences \& Research Centre, Bangalore, Karnataka, India.

\section{ABSTRACT}

Background: Assessment is one of the most important aspect of teaching and learning process. Various assessment methods are available to assess the knowledge $\&$ skills of students. The objective of the study was to know views of the students regarding the best assessment method in anatomy.

Materials and methods: Inputs from 200 MBBS students were collected who completed first year MBBS. A questionnaire which included questions relating to various assessment techniques for theory \& practical internal exams in anatomy was used to get the feedback from the students.

Results: Majority students felt that internal assessment should be conducted thrice in a year. The assessment methods preferred by them was written test for theory in the form of SAQ \& SEQ and MCQ also should be included in it. Many students felt that internal assessment should be the criteria for allowing students to appear in university examinations but disagreed to include the internal assessment marks in university examination.

Conclusion: It is important to obtain more frequent feedback from the students which will help teachers to modify the assessment methods and improve the standards of medical education.

KEY WORDS: Internal Assessment, Student, Method, Feedback, Anatomy.

Address for Correspondence: Dr. Swapnali Shamkuwar, A-902, Skylark Esta Apartment, Hoodi Graphite Main Road, Near Kamat Yatriniwas, Hoodi, Bangalore. 560048, Karnataka, India.

Mobile no.-8095342774 E-Mail: drswapnalis@gmail.com

Access this Article online

Quick Response code

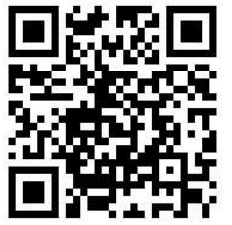

DOI: $10.16965 /$ ijar.2019.264

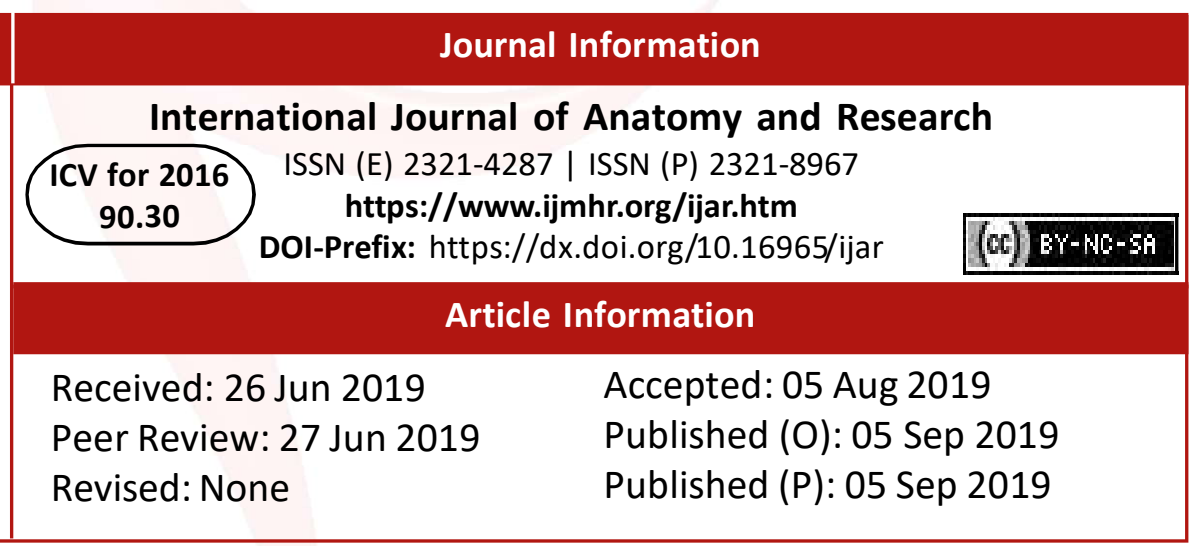

\section{INTRODUCTION}

A systemic process of collecting, analysing and interpreting data in order to validate or judge students is assessment. It is one of the most important aspect of teaching and learning process [1]. Traditionally assessment was done at the end of the term or the academic year. Later internal assessment was introduced in medical curriculum [2]. The impact of assessment on student learning is profound. Recent research suggests that examinations are more powerful drives of student learning [3-4]. It also measures knowledge and competence and provides feedback to teachers and learners [5].

A wide range of assessment methods currently available include essay questions, modified essay questions (MEQs), multiple choice questions (MCQs), objective structured clinical examination (OSCE), student projects, short case assessment and long case assessment, logbook, video assessment, simulators, peer assessment and standardized patients [6]. Medical anatomy is an important subject of first year of MBBS course. Progress of students in anatomy is 
assessed by using written, practical \& viva voce examination. Practical assessment is done with the help of spotters \& discussions on already dissected specimens and viva voce on bones and models. In a written examination the questions can be asked in different ways eg. Long essay questions (LAQ), short essay questions (SEQ), short answer questions (SAQ) and (MCQs) [7].

LAQ assesses critical thinking skills and writing abilities of student but limited content of subject is assessed [8]. SAQ is an open ended semi structured question format and larger portion of the subject can be evaluated [6].

Structured essay question (SEQ) is an open ended question containing structured components and expects specific answers to those components. These questions are used to test the knowledge as well as the capacities of analysing, reasoning, application and integrating. SEQ helps in evaluation of interpretative skills [9].

MCQ $s$ are reliable, valid and assess the large amount of knowledge but less powerful to assess problem solving skills of students [10].

It is necessary to review the assessment methods at regular intervals. Various evaluation tools such as students feedback help the faculty to identify the strong \& weak points of their assessment methods and allows to modify and improve the assessment method [11]. With this background this study was undertaken to assess the student perception about frequency, interval \& format of internal assessment in anatomy.

\section{MATERIALS AND METHODS}

200 MBBS students in Vydehi Institute of Medical Sciences \& Research Centre, Bangalore were exposed to regular teaching pattern in anatomy. We conducted three internal examinations for theory \& practical as well as part ending tests were also carried throughout the year. This study was conducted once the students had completed their first year MBBS examination. A specially designed questionnaire was developed which included close ended questions relating to various assessment techniques for theory \& practical internal exams in anatomy. Students were also asked to suggest improvements in assessment techniques. The questionnaire was explained to students. They were asked not toreveal their identity while answering the questionnaire. Data thus obtained was analysed considering each question of the questionnaire.

Table 1: Perception of students regarding internal assessment in anatomy.

\begin{tabular}{|c|c|c|c|c|}
\hline Number & Questions & Options & $\begin{array}{l}\text { Number of } \\
\text { students }\end{array}$ & $\%$ \\
\hline \multirow{4}{*}{1} & \multirow{4}{*}{$\begin{array}{l}\text { How frequently the internal } \\
\text { assessment should be } \\
\text { conducted }\end{array}$} & a. weekly & 7 & $3.50 \%$ \\
\hline & & b. Once in a month & 30 & $15 \%$ \\
\hline & & c. $\quad$ Part completion & 53 & $26.50 \%$ \\
\hline & & d. Thrice in a year & 110 & $55 \%$ \\
\hline \multirow{3}{*}{2} & \multirow{3}{*}{$\begin{array}{l}\text { Internal assessment } \\
\text { examination should be } \\
\text { conducted for }\end{array}$} & a. $\quad$ Theory & 9 & $4.50 \%$ \\
\hline & & Practical & 5 & $2.50 \%$ \\
\hline & & Both theory \& practical & 186 & $93 \%$ \\
\hline \multirow{2}{*}{3} & \multirow{2}{*}{$\begin{array}{l}\text { How many marks a theory } \\
\text { paper should have? }\end{array}$} & a. 50 marks & 36 & $18 \%$ \\
\hline & & b. 100 marks & 164 & $82 \%$ \\
\hline \multirow{3}{*}{4} & \multirow{3}{*}{$\begin{array}{l}\text { Which type of question is the } \\
\text { best form of assessment? }\end{array}$} & a. Long question & 14 & $7 \%$ \\
\hline & & b. Short essay & 105 & $52.50 \%$ \\
\hline & & c. Short answers & 81 & $40.50 \%$ \\
\hline \multirow{3}{*}{5} & \multirow{3}{*}{$\begin{array}{l}\text { Which type of question is } \\
\text { easier to answer? }\end{array}$} & a. Long essay & 23 & $11.50 \%$ \\
\hline & & b. $\quad$ Short essay & 61 & $30.50 \%$ \\
\hline & & Short answers & 116 & $58 \%$ \\
\hline \multirow{3}{*}{6} & \multirow{3}{*}{$\begin{array}{l}\text { Which type of questions will } \\
\text { fetch more marks? }\end{array}$} & a. Long essay & 11 & $5.50 \%$ \\
\hline & & b. $\quad$ Short essay & 53 & $26.50 \%$ \\
\hline & & Short answers & 136 & $68 \%$ \\
\hline \multirow{3}{*}{7} & \multirow{3}{*}{$\begin{array}{l}\text { Which type of question is } \\
\text { time saving? }\end{array}$} & a. Long essay & 3 & $1.50 \%$ \\
\hline & & b. short essay & 12 & $6 \%$ \\
\hline & & c. short answers & 185 & $92.50 \%$ \\
\hline \multirow{3}{*}{8} & \multirow{3}{*}{$\begin{array}{l}\text { Which type of question test } \\
\text { knowledge of the topic? }\end{array}$} & a. $\quad$ Long essay & 52 & $26 \%$ \\
\hline & & b. Short essay & 67 & $33.50 \%$ \\
\hline & & c. Short answers & 81 & $40.50 \%$ \\
\hline
\end{tabular}


Table 2: Perception of students regarding internal assessment in anatomy.

\begin{tabular}{|c|c|c|c|c|}
\hline Number & Questions & Options & $\begin{array}{c}\text { Number of } \\
\text { students }\end{array}$ & $\%$ \\
\hline \multirow{3}{*}{9} & \multirow{3}{*}{$\begin{array}{l}\text { Do yo think the questions asked are } \\
\text { relevant? }\end{array}$} & a) Agree & 178 & $73.50 \%$ \\
\hline & & b) disagree & 7 & $3.50 \%$ \\
\hline & & c) neither agree or disagree & 15 & $7.50 \%$ \\
\hline \multirow{3}{*}{10} & \multirow{3}{*}{$\begin{array}{l}\text { Adequate time was allotted for } \\
\text { writing the theory paper? }\end{array}$} & a) Agree & 159 & $70.50 \%$ \\
\hline & & b) Disagree & 23 & $11.50 \%$ \\
\hline & & c) Neither agree or disagree & 18 & $9 \%$ \\
\hline \multirow{3}{*}{11} & \multirow{3}{*}{$\begin{array}{l}\text { Should MCQ be included in theory } \\
\text { paper? }\end{array}$} & a) Agree & 126 & $63 \%$ \\
\hline & & b) Disagree & 25 & $12.50 \%$ \\
\hline & & c) Neither agree or disagree & 49 & $24.50 \%$ \\
\hline \multirow{3}{*}{12} & \multirow{3}{*}{$\begin{array}{l}\text { Was internal examination leading } \\
\text { to absentees in the class? }\end{array}$} & a) Agree & 149 & $74.50 \%$ \\
\hline & & b) Disagree & 27 & $13.50 \%$ \\
\hline & & c) Neither agree or disagree & 24 & $12 \%$ \\
\hline \multirow{3}{*}{13} & \multirow{3}{*}{ Was internal examination stressful? } & a) Agree & 147 & $73.50 \%$ \\
\hline & & b) Disagree & 22 & $11 \%$ \\
\hline & & c) Neither agree or disagree & 31 & $15.50 \%$ \\
\hline \multirow{3}{*}{14} & \multirow{3}{*}{$\begin{array}{l}\text { Should internal assessment be the } \\
\text { criteria for allotting students to sit } \\
\text { in university exams? }\end{array}$} & Agree & 92 & $46 \%$ \\
\hline & & b) Disagree & 66 & $33 \%$ \\
\hline & & c) Neither agree or disagree & 42 & $21 \%$ \\
\hline \multirow{3}{*}{15} & \multirow{3}{*}{$\begin{array}{l}\text { Should internal assessment marks } \\
\text { be included in university exams? }\end{array}$} & a) Agree & 58 & $29 \%$ \\
\hline & & b) Disagree & 92 & $46 \%$ \\
\hline & & c) Neither agree or disagree & 50 & $25 \%$ \\
\hline \multirow{3}{*}{16} & \multirow{3}{*}{$\begin{array}{l}\text { Best assessment technique for } \\
\text { practical examination }\end{array}$} & a) Viva on soft parts & 85 & $42.50 \%$ \\
\hline & & b) Viva on hard parts & 13 & $6.50 \%$ \\
\hline & & Viva on models & 22 & $11 \%$ \\
\hline
\end{tabular}

Table $1 \& 2$ shows the perception of undergraduate students towards the internal examination. As evident from the table many students opined that the internal examination should be conducted thrice in a year for both theory \& practical examination. In the present study many of the students felt that a theory paper should carry maximum 100 marks. Short essay question (SEQ) was considered as the best form of assessment in theory by $52.5 \%$ of students. Majority of the students favoured short answer questions (SAQ) over other two formats as it was easier to answer, time saving \& fetch more marks. With regard to a method to test the knowledge of the topic SAQ was preferred by $40.5 \%$ of students followed by short essay question (33.5\%). Further analysis of data revealed that $63 \%$ of students agreed to include MCQ in theory paper. In terms of questions asked were relevant $89 \%$ of students answered in the affirmative. Majority of the students (79.5\%) felt that time allotted for writing the theory paper was adequate. Best assessment technique to measure skills in practical exam should be viva voce on dissected parts (42.5\%) followed by spotter examination (40\%). Most of students agreed that internal examination is stressful \& cause of absentees in the class. In the present study 92(46\%) students felt that internal assessment should be the criteria for allowing students to appear in university examinations and 66(33\%) students were disagree for it. There was disparity in students about including internal assessment marks in university exams. $46 \%$ of students disagreed whereas $29 \%$ of students agreed to add the internal assessment marks in university exams.

\section{DISCUSSION}

Assessment is central to the educational process. It shows how well students have learnt the subject [5]. Interim assessment stimulates student to learn better and to increase their score of the final examination [12].

In our study majority of students preferred internal assessment should be conducted for 
both theory \& practical examination. Considering the interval of internal assessment about $55 \%$ students preferred test three times in a year. In study by S K Nagar et al. [13]. 70.80\% students preferred weekly test whereas in study conducted by Rashmi Jaiswal et al. [14]. 47\% students were in favour of part completion test and in study by Chakrabarti S et al. [15]. 55\% students preferred monthly assessment.

In our study many students felt that a theory paper should carry maximum 100 marks. In terms of best form of assessment in theory short essay question (SEQ) was preferred by $52.5 \%$ of students in the present study which is similar to the study conducted by Rafique et al. (38.8\%) [11]. In the study by Jaiswal et al. [14] 55.03\% students favoured combination of descriptive and short essay questions with multiple choice questions whereas in study conducted by Chakrabati et al. [15] students preferred short answer questions (SAQ) as the best method of assessment. Majority of students in the present study favoured SAQ over other two formats as it was easier to answer, time saving \& fetch more marks as well as test the knowledge. A study done among second year students of Subbaiah medical college [16] revealed that SEQ helps to fetch more marks whereas in study by Sharma et al [9] found that MCQ scores are higher than SEQ scores.

In present study $63 \%$ of students recommended to include MCQ in theory. In RGUHS (Rajiv Gandhi University of Health Sciences) a combination of long essay questions, short essay questions $\&$ short answer questions are presently used for assessment of theory. Many undergraduate students were satisfied with the questions asked in the written examination $(89 \%)$ and allotment of sufficient time for writing theory paper (79.5\%). In the present study best assessment technique for conducting practical examination was viva voce on dissected parts (42.5\%) followed by spotter examination (40\%) which is similar to study done by Jaiswal $R$ et al. [14] in the study by Chakrabarti et al. [15] students preferred combination of spotter, discussion on gross specimen \& discussion on histology.

Most of the students agreed that internal examination is stressful and cause absentees in the class. $46 \%$ of students felt that internal assessment should be criteria for allowing students to appear in university examinations whereas in study done by Jaiswal et al. [14] only $29.4 \%$ students agreed for performance in internal assessment should be considered. In the study by Rafique et al. [11] $55.7 \%$ students felt that internal assessment \& class attendance both should be taken into consideration for allowing students to appear in university examination. There was disparity in students about including internal assessment marks in university exams. $46 \%$ of students disagreed whereas $29 \%$ of students agreed to add the internal assessment marks in university exams.

\section{CONCLUSION}

Overall students were satisfied with the internal assessment. The assessment methods preferred by them was written test for theory in the form of SAQ \& SEQ and MCQ also should be included in it. Majority of students opined that best assessment technique for practical examination should be viva voce on dissected parts and internal assessment should be conducted thrice in a year. Many students felt that internal assessment should be the criteria for allowing students to appear in university examinations but disagreed to include the internal assessment marks in university examination.

This study shows that there is a constant need for modification and improvement of assessment methods. It is important to obtain more frequent feedback from the students which will help teachers to modify the assessment methods and improve the standards of medical education.

\section{ABBREVIATIONS}

MEQ - Modified essay question

MCQ - Multiple choice question

OSCE - Objective structured clinical examination

LAQ - Long easy question

SEQ - Short essay question

SAQ - Short answer question

Conflicts of Interests: None

\section{REFERENCES}

[1]. Aalaei S, Azizi M Ahmadi T, Aalaei A. Comparison of Multiple-Choice and Essay Questions in The Evaluation of Dental Students. International Journal of Advanced Biotechnology and Research 2016; 7(5): 1674-1680. 
[2]. Panchbhai A, Vagha S, Bhowate R. Perception of students and faculties regarding the formative assessment examinations in dental college in India. Journal of Education and Ethics in Dentistry 2014;4(2); 47-53.

[3]. Cilliers F J, Schuwirth L W, Adendorff H J, Herman N, Vleuten C P.The mechanism of impact of summative assessment on medical students' learning. Adv in Health Sci Educ 2010; 15:695-715.

[4]. Raupach T, Brown J, Anders S, Hasenfuss G, Harendza S. Summative assessments are more powerful drivers of student learning than resource intensive teaching formats. BMC Medicine 2013;11;61.

[5]. Hift RJ. Should essays and other open ended type questions retain a place in written summative assessment in clinical medicine? BMC Medical Education 2014; 14: 249.

[6]. Tabish S A. 2009. Assessment Methods in Medical Education. International journal of health sciences 2008; 2(2); 3-7.

[7]. Wallerstedt S, Erickson G, Wallerstedt SM. Short answer questions or Modified essay QuestionsMore than a technical issue. International Journal of Clinical Medicine 2012. 3:28-30.

[8]. Reiner CM, Bothell TW, Sudweeks RR, Wood B. How to prepare effective essay questions: guidelines for University Faculty. BYU Faculty center, Brigham Young University Testing Services, Department of Instructional Psychology and Technology 2002;5.

[9]. Sharma HS, Mutalik MM. Questions and Structured essay questions at III MBBS examination in Otorhinolaryngology in a Medical college in Mauritius. Int J Pharm Bio Sci 2014;5(4):1195-202.

[10]. Khan M, Aljarallah BM. Evaluation of Modified Essay questions (MEQ) and Multiple Choice Questions (MCQ) as a tool for assessing the Cognitive skills of Undergraduate Medical Students. Int J Health Sci (Qassim) 2011;5(1):45-51.
[11]. Rafique S, Rafique H. Student's feedback on teaching and assessment at Nishtar Medical College, Multan. J Pak Med Assoc 2013;63(9):1205-09

[12]. Bekkink M O, Donders R, Van Muijen G N P, Ruiter D J.Challenging medical students with an interim assessment: a positive effect on formal examination score in a randomized controlled study. Adv in Health Sci Education (2012) 17:27-37.

[13]. Nagar S K, Malukar O, Kubavat D, Prajapati V, Ganatra D, Rathwa A. Students perception on anatomy teaching methodologies. National journal of medical research. 2012;2(1):111-112.

[14]. Jaiswal R, Sathe S, Gajbhiye V, Sathe R. Students Perception on Methods of Anatomy Teaching and Assessment, International Journal of Anatomy and Research 2015; 3(2):1103-08.

[15]. Chakrabarti S, Raghunath G, Vijayalakshmi. Challenges in learning Anatomy by first MBBS students of 2016-17 batch its difficulties and assessment methods preferred by them - a feedback study. Indian Journal of Clinical Anatomy and Physiology 2018; 5(3): 416-421.

[16]. Naik T B, Upadhya A K, Swarooprani N B, Wadekar $M D$, Mane V, BiradarA. Students perception on different formats of written assessment in medical education. Journal of Educational Research \& medical Teacher 2015; 3(1): 8-12.

$$
\begin{aligned}
& \text { How to cite this article: } \\
& \text { Swapnali Shamkuwar, Varsha Mokhasi. STUDENTS PERCEPTION } \\
& \text { ON INTERNAL ASSESSMENT IN ANATOMY. Int J Anat Res } \\
& \text { 2019;7(3.3):6939-6943. DOI: } 10.16965 / \text { ijar.2019.264 }
\end{aligned}
$$

